\title{
The Institutional Staging of an Examination
}

\author{
DANIEL ALBAS* and CHERYL ALBAS*
}

\begin{abstract}
This study employs the dramaturgical approach to the staging of examinations. In focusing on the staging we attempt to convey the university definition of the exam as well as the means by which institutionally desired moods and actions are communicated to students. Through the use of space, props, equipment, and human actors the university stresses the larger societal values of universalism and individual achievement. In so doing the university develops a "rhetoric of idealization" to compensate for the inevitable discrepancies in fairness and equality of treatment.
\end{abstract}

\section{RÉSUMÉ}

Cette étude part de l'aspect théâtral qui entoure l'organisation des examens. En fixant notre attention sur la mise en scène qui la caractèrise, nous tâchons de montrer ce qu' est un examen pour l'université et par quels moyens l'institution transmet aux étudiants l'état d'esprit et les attitudes qu' elle désire obtenir. Par l'utilisation qu'elle fait de l'espace, des accessoires, de l'équipement et de ses acteurs, l'université met l'accent sur les grandes valeurs sociales que sont l' universalisme et la réussite individuelle. Ce faisant, l' université encourage chez l'étudiant une "rhétorique de l'idéalisation" dont le but est de compenser une utilisation de la justice et de l'égalité inévitablement pleine de contradictions.

\section{The Examination as Dramaturgy}

The dramaturgical approach to the understanding of social interaction stresses the contention that meaning is conveyed by actors when they interact with each other, not only through verbal discourse ${ }^{1}$ in which the meanings are mutually shared but

\footnotetext{
*Department of Sociology, University of Manitoba
}

An earlier version of this paper was presented at the Qualitative Research Conference, Waterloo, Ontario, Canada. The authors wish to thank D. Rennie for comments on earlier drafts of this work.

${ }^{1}$ This sharing of the meanings in verbal discourse is in contrast to the McHugh and Garfinkel experiment in which the experimenters gave the subjects garbled, nonsense replies to their questions toward defining a situation (see Perinbanayagam, 1974). 
also through mood, facial expression, gesture, deportment, and the whole panoply of dramatic body language. In effect, actors work at giving a certain desired impression (i.e., defining the situation) and call upon all their talents and possessions to do so -- much as is done in drama, except that in drama the plot is fictitious and so are the actors' personae. In dramaturgy, actors are projecting their own personae as they wish them to be perceived, and the defined situations, unlike the plots in drama, form, dissolve, and reform as the interaction progresses.

As in drama, actors use not only their bodies to convey impressions, but also "props" and "equipment" such as a pipe, furniture, or food in the full knowledge that objects have symbolic meanings and can be used to dramatize an intended message in the same way that, as Milton put it, "the dim religious light and the organ's pealing notes" [in a church] "bring all heaven before the eyes".

It is no reification to speak of an institution as an actor if the actions being referred to are those of the institution's functionaries acting officially on its behalf. In this study the focus is upon the use of space, props, equipment, and human actors (invigilators) by the university in the staging of examinations. In focusing on the staging we attempt to convey the university's definition of the exam as well as the means by which institutionally desirable moods, thoughts and actions are communicated to students. In our urban, bureaucratic, and industrialized society exams are important, serious, formal affairs arranged and administered to reflect larger societal values of universalism and individual achievement.

The themes of individualism and competitive achievement are relatively recently emphasized societal values that came to be stressed with the development of industrial capitalism, and so were only recently incorporated into the message transmitted by the staging of exams. As late as 1778, according to Broadfoot (1979) final examinations at Oxford were informal, nonserious, trivial affairs.

\section{Methodology}

The data for this study were drawn from a larger study, still ongoing, of student life and examinations. The data gathering took place, primarily at one university, over the past fifteen years. The data consist of observations made by us as we acted as invigilators at examinations and as we observed other invigilators. In addition, information came from thirty hour long tape recorded interviews with other invigilators. The objects of our observations and interviews were the layouts of the examination rooms as to their size, furnishings and arrangement as well as the practices employed by invigilators in distributing papers and supervising the conduct of examinations, as well as the students who wrote. Where, for example, we observed invigilators scrupulously straightening partitions between tables or aligning chairs before students entered the rooms to write, we asked them either on the spot or later in interviews why exactly they did what they were observed to do. In addition, we conducted interviews with university personnel in charge of arranging and staging examinations. Finally, insights were gleaned from official historical documents. This university is unique in that it began originally as solely 
an examining body for the various colleges in the province, and only later became a teaching and research institution as well.

In effect, this paper is specifically our construction of what we impute the university message to the students to be, based on information from university officials and our own observations, and the description of this within a framework of dramaturgical insights and terminology.:

In drama and dramaturgy there have to be both actors and audience; the interaction consists of the effect that the one has on the other, that the other has on the one and both of these. The focus of this study is not on the interaction, but on the message and the media. (A forthcoming paper will describe the response of the audience (i.e., the students) to the actor's (i.e., the university's) message.)

In discussing the message, we raise the question (that might be important for the philosophy of education) of the necessity for a "rhetoric of idealization" on the part of the university to preserve the fragility of the universalism/personal achievement dialectic. This aspect too is being developed elsewhere.

\section{The Components of an Examination Staging}

\section{SPACES}

Space is one essential ingredient of every social situation. Since space is invested with social meanings, transactions take on varying significance depending on the arrangement of the spaces within which they occur. In the case of exams, they are frequently written in places "apart" from classrooms where much of the routine learning occurs. Final exams are often administered in great halls such as gymnasia. The horizontal expanse of the area plus the soaring ceiling tends to add ceremonial importance to the event and perhaps suggests that lofty (or at least "mind stretching") activities are expected. Authorities tend to demand that, students distribute themselves as far apart from each other as possible. Such an arrangement creates more body space for students than they usually have for lectures. Hall (1966:95) indicates that larger than usual spaces are conducive to formulating "big thoughts in big words". Hence, the institutional provision of large spaces for final exam settings, or having students sit farther apart than they usually do in class tests, sets the stage for a mood of seriousness, heightens cognitive demands, and facilitates their execution.

Announcements which appear on official university bulletin boards approximately two weeks prior to the event, inform students of the location of their exam and of their "area" within the larger spaces. For example, students of Biology 77:120 Section 4 will be slated to write in Bison East Gym and to occupy writing spaces numbered 1-200. The considerable effort and expense the institution incurs to set a formal stage for examinations is evidenced by the public announcement and assignment of classes to writing areas, subsectioning classes within areas and meticulously pre-arranging props. The inescapable collective message is that what is happening is important. 
PROPS

The selection, arrangement, and control of props provide a further set of cues which guide exam related moods, thoughts, and actions. Props are physical objects arranged in settings in advance of official transactions and remain more or less stationary throughout the transaction (Gross and Stone, 1981). The major exam related props consist of long tables, plywood partitions designed to be clamped on to the tables to mark off students' individual writing spaces, and chairs. They are systematically arranged so that vast ranges of human conduct are limited to that deemed appropriate by the authorities. Each writing space is numbered and students from the same class sit in an area identified by a prearranged sequence of numbers.

The more immediate institutional intent of this arrangement is to convey a sense of ordered formality, even solemnity. The orderly arrangement of props has implications not only for mood, but also for thoughts and actions. To enter such a formally ordered space to write an exam suggests that however scrambled and fluid the information may be in the students' minds, in this setting it is expected to be organized and coherent. In other words a "certain bureaucratization of the spirit is expected" (Goffman, 1959:56). In terms of actions, the implicit message given to students by the straight row seating arrangement is "look straight ahead" only. Performances are to be solo and not the result of a team effort.

The aim of providing students with a distraction-free environment is secondary to that of ensuring that students compete according to universalistic standards. If the goal were to be primarily shielding them from distraction, the dividers would be extended to prevent students from looking ahead, as is the case with library study carrels. The absence of front panels can be partially explained by reasons of economy; the more basic explanation is that they are not absolutely necessary to prevent cheating. All that students can normally see in front of them are the backs of the persons ahead, not their exam papers. In the same vein, the tables at which students sit do not come equipped, as do office desks, with modesty panels to hide views of the legs and possible hand movements. The obvious reason for a lack of these panels once again is economy; however, the result is that students are open to surveillance. The implication is that they must exercise control not only over head and eye movements but also over hands. Any reaching for crib notes or books becomes observable to invigilators.

As we have seen, the selection and arrangement of examination room props indirectly communicate desired student behaviour. At the same time these props are also strategic in controlling behaviour. Students sit shoulder to shoulder along straight rows of tables. Students are arranged at angles so as to minimize communication. Any move to alter the arrangement by, for example, leaning back in the chairs, pulling chairs closer together, or angling heads for communication presents an immediately observable break in symmetry and calls attention to the persons involved. In this way, then, it is difficult for students to conceal actions which are at variance with the rules of the occasion. These highly observable actions are more easily controlled by invigilators. 
In all exam situations where an effort is made to dramatize universalistic, individual achievement themes, there is an institutional concern with isolating writers of the same exam from each other. From early records of examination settings, we find that barriers between writers were consciously erected to facilitate the institutional definition of the situation. By 1894, a participant in an Oxford Local Examination writes that "boys who undergo the examination sit at desks about a yard apart from one another, so that they cannot look over each other's papers or take any unfair advantage" (Roach, 1971:181). In institutions that have sufficient space this is still the most frequent mode of social control; students typically are seated in gymnasia at single desks located some distance from each other. In classroom situations professors frequently ask students to leave an empty seat between them and their neighbours. An historical form of extreme insulation occurred at the Imperial University in Peking where, instead of desks, there were rows of "examination cells" - fully enclosed hut-like structures which gave the impression of rows of outhouses - each containing a single writer (Monroe, 1918).

By staging a setting to ensure that student performances are in accordance with the tenets of universalism and individual achievement, the unfortunate impression created is that all students cannot be fully trusted to conduct themselves according to these standards. More specifically, students are not allowed to display the internalized values of honour and trust through attitudinal conformity (Merton, 1959). Rather, the high degree of control and observability typical of exams produces [a situation suggestive of] behavioural conformity. The impression of mistrust created is so pervasive that it might be described as a suspicion awareness context (Glaser and Strauss, 1981). Seating students farther apart than usual, placing "cheat partitions" between them, providing instructions regarding placement of other props such as books, notes, and ID cards, all contribute to this suspicion awareness context. Students must leave notes and books at the front or along the sides of the room. In the case of in-class tests all books are deposited out of easy reach of the writer, either in an empty adjacent seat or on the floor; here they function merely as props or decor, not as equipment to be handled during a transaction. A further sense of mistrust is generated when students are required to produce identity documents before they are allowed to write the examination. These cards contain plastic coated, sealed student photos to prove that they are indeed the persons they purport to be.

\section{EQUIPMENT}

Staging a social situation requires not only static elements such as spaces and props but also equipment that can be manipulated. The major equipment items used for examinations are the exam questionnaires, the booklets provided for answers, and IBM sheets. The questionnaires usually have a formal air about them. The printing is usually offset rather than duplicated in the department; the paper itself tends to be legal rather than regular size; and the precise time (e.g., 9:00 a.m. to 12:00 p.m.) as well as date are listed. In the case of multiple choice questions the worth 
of each, and the overall proportion of the exam they comprise, are also listed. The questionnaires have each page numbered and on each page it is specified how many pages there are in total (e.g., page 2 of 10 pages). Instructions on the answer booklets also require detailed information from students. Each must specify his/her complete name, student number, year in program, course number and section, as well as name of instructor, the present date, and the location in which the exam is written.

A final piece of equipment in the examination setting is a sticker designed to conceal students' identity (name, student number, and seat number) on answer booklets. Students are formally instructed to "affix flap" to the relevant information and not to indicate in any manner their name, student number, or address on any other part of the book. The practice is designed to convey an impression of universalism to students. For professors, it reminds them of their responsibilities outside the examination room. They are to read and evaluate all answers impartially, regardless of special relationships they may have formed with particular students. The role of the "flap", however, is more dramatic than real because the grading process is not open to observation by outside authorities and there is nothing but their integrity to prevent professors from violating the norm if they were so inclined. Also, over the year most professors come to recognize the writing styles and even the handwriting of at least some students. It is interesting to note, though, that the impression created is that professors, (even though they are not open to surveillance), can be relied upon to conduct themselves according to universalistic principles.

The presence of a formal set of questions which demand answers, the ample supply of exam booklets waiting to be filled up, and a strict time barrier suggests that a pressure-packed student performance is expected. The message derived from this institutional equipment is reinforced by the props in the environment. The furnishings are totally utilitarian; there is little that yields to the body, is soft to the hand, or warm to the eye. These ascetic conditions then set the stage for the ordeal.

Earlier we described how the arrangement of props in the examination setting conveyed a suspicion awareness context. The equipment the university strategically includes or, perhaps more importantly, excludes reinforces this impression. Despite considerable expense, the university insists on providing all answer booklets. The impression given is that all students cannot be trusted to conduct themselves in accordance with the principles of universalism and individual achievement. As one invigilator says: "if students had to supply their own paper, some would inevitably be short and resort to borrowing and lending which, in turn, would generate obligations of gratitude that may extend to unfair help and collaboration".

Each booklet contains a list of formally printed instructions: "Candidates must not have in their possession at the time of the examination any unauthorized books, tables, notes or any other extraneous material". "Rough work must be confined to left hand pages". "Do not tear any pages out of this book". "Return all booklets 
received whether used or not". The implication again is that students might bring crib notes into the examination room or smuggle out booklets to use themselves at a later date or perhaps to pass on to friends.

The selection and layout of stage space, props, and equipment suggests the presence of two types of bodies - professors and students. The symmetrical arrangement of row upon row of desks, each equipped with exactly the same writing materials implies that the students who occupy these spaces will be preoccupied with the task of thinking and writing. Props and equipment are arranged so that all students face a single larger table set some distance to the front of the desks. Behind this table are a small number of chairs. The table is distinguished by an absence of "cheat partitions" and exam or answer booklets. This type of arrangement facilitates communication. The lack of a competing involvement in the form of exam booklets, the ability to observe all of the students, and at the same time to be easily seen by them, suggests that observation is the professors' dominant involvement.

The presence of more than one authority figure (professor) is a feature that strikingly distinguishes exams from routine classroom encounters. The presence of several professors not only adds to the atmosphere of formality and seriousness, it also emphasizes the suspicion awareness context because they are now labelled "invigilators".

The identities of invigilators and students are spatially distinguished along both horizontal and vertical dimensions. Students remain seated throughout the exam while invigilators are permitted, even expected, to stand and to move about the area. Standing makes invigilators appear forceful, adds to their authority, and so helps to ensure that student behavior is within acceptable bounds. Some of the most dramatic illustrations of the "vertical dimensions" of spatial behavior occurred during in-class exams. In one instance the professor, when he was not moving around the room answering students' questions, spent the time sitting at his desk on a dias which occupied the entire front of the room. Four additional invigilators, two on either side of his desk, stood with arms crossed, peering down at the students during the entire period. The more extreme example involved a foreign graduate student who was assisting in the invigilation process. As soon as the professor signalled students to begin writing, this graduate student mounted the dias, pulled out the chair from behind the desk, and used the chair as a step to climb on to the desk top. He then stood with crossed arms and glared down at the students for the duration of the exam!

\section{Conclusion}

Whereas in the past, examinations were thought of as serving the single manifest function of screening and accrediting students for positions in the workworld, the findings of this paper have unearthed two further latent functions. First, the dramaturgical perspective has provided us with a means of demonstrating pointedly what might not in the past have been very clear and certainly never 
explicitly stated, namely the dramatization of societal values of individualism and universalism.

Second, another function of the examinations that is not manifest and perhaps not even admitted to, is the fact that having students "slug it out" in such highly scripted settings also serves to deflect attention from discrepancies in the meritocratic ideal in the educational system which emphasizes reward on the basis of equal competition. However, in no way can the upper and lower classes be considered to start off evenly matched due to the great discrepancies in their respective backgrounds and opportunities. As a consequence, students from privileged social backgrounds regularly perform better than do their less privileged counterparts (Jencks, 1972). Also, the impression generally given is that all students are tested on exactly the same basis. In actuality, examinations in the same subject discipline tend to vary in difficulty and content from section to section of a course, and from year to year, and different instructors employ different standards of grading (Hughes, et al., 1962; Becker, et al., 1968). Such discrepancies create the need for a "rhetoric of idealization." This rhetoric takes the form of an exaggerated emphasis on the shows of fairness and equality which, as in the case of Lady Macbeth, suggest that the institution might be protesting too much, and wherever there is over-protest one searches for a sense of guilt and for attempts to cover it. Examinations in their staging, represent an idealized attempt on the part of the university to hide their failings to achieve the ideals they profess. In effect, as in the case of all ideals, practice of them often falls short and so it becomes necessary to propagate a rhetoric to shore them up. This, then, has been the essential character of our discussion of the scripted nature of examinations.

It should be made clear that the preceding discussion did not assume that the university deliberately and explicitly set out to send the messages suggested. The actual situation was most probably that from the earliest days of examinations it was necessary to find ways to prevent cheating and so achieve fairness. Instituting these measures inevitably generated a number of latent consequences which included giving off impressions of seriousness, individualism, and universalism. These latent consequences became almost manifest because they could be so obviously argued to fit the industrial bureaucratic context within which the university is now located.

\section{REFERENCES}

Albas, D. and C. Albas (1984). Student Life and Exams: Stresses and Coping Strategies. Dubuque, IA: Kendall/Hunt.

Becker, H. and B. Greer (1968). Making the Grade: The Academic Side of College Life. New York: Wiley.

Broadfoot, P. (1979). Assessment, Schools and Society. London: Methuen.

Glaser, B. and A. Strauss (1967). "Awareness contexts and social interaction." American Sociological Review 29: 669-679.

Goffman, E. (1959). Presentation of Self in Everyday Life. Garden City, NY: Doubleday.

Gross, E. and G. Stone (1981). "Embarrassment and the analysis of role requirements." in G. Stone 
and H. Farberman (eds.), Social Psychology Through Symbolic Interaction. (2nd ed.) New York: Wiley.

Hall, E. (1966). The Hidden Dimension. Garden City, NY: Doubleday.

Hughes, E. et al. (1962). "Student culture and academic effort." In N. Sanford (ed.) The American College: A Psychological and Social Interpretation of Higher Learning. New York: Wiley. Jencks, C. (1972). Inequality. New York: Basic.

Merton, R. (1959). "Conformity, deviation, and opportunity structures." American Sociological Review 24: 177-188.

Monroe, P. (1918). A Textbook in the History of Education. London: Macmillan.

Perinbanayagam, R. (1974). "The definition of the situation and an analysis of the ethnomethodological and dramaturgical view." Sociological Quarterly 15: 521-542.

Roach, J. (1971). Public Examinations in England. London: Cambridge University Press. 